\title{
Characterization of Human Platelet Vasopressin Receptors
}

\author{
Marc Thibonnier and James M. Roberts
}

Department of Pharmacology, Department of Obstetrics, Gynecology and Reproductive Sciences, and Cardiovascular Research Institute, University of California, San Francisco, California 94143

\begin{abstract}
Using tritiated arginine-8-vasopressin $\left[{ }^{3} \mathrm{H}\right] \mathrm{AVP}$, vasopressinspecific binding sites were detected on human platelet membranes. One class of high-affinity binding sites was characterized with an equilibrium dissociation constant of $1.01 \pm 0.06 \mathrm{nM}$ and a maximal binding capacity of $100 \pm 10 \mathrm{fmol} / \mathrm{mg}$ of protein ( $n$ =12). Highly significant correlations were found between the relative agonistic $(r=0.87, P=0.002)$ or antagonistic $(r=0.99$, $P=0.007)$ vasopressor activities of a series of 13 AVP structural analogues and their relative abilities to inhibit $\left[{ }^{3} \mathbf{H}\right] \mathbf{A V P}$ binding to platelet receptors whereas no such relationship existed when antidiuretic activities were considered $(r=0.28, P=0.47)$. AVP did not stimulate cyclic AMP production of human platelets; on the contrary, high AVP concentrations $\left(10^{-6} \mathrm{M}\right)$ inhibited cyclic AMP production measured in basal and prostaglandin $\mathbf{E}_{1}$-stimulated conditions. AVP caused intact platelet aggregation with a half-maximal aggregation $\left(\mathrm{EC}_{50}\right)$ of $28 \pm 2 \mathrm{nM}$. This effect was more potently reversed by the specific vascular antagonist $\mathrm{d}\left(\mathrm{CH}_{2}\right)_{5} \mathrm{Tyr}(\mathrm{Me}) \mathrm{AVP}(\mathrm{pA2}=\mathbf{8 . 1 0} \pm 0.23)$ than by the specific renal antagonist $d\left(\mathrm{CH}_{2}\right)_{5}$ IleuAlaAVP $(\mathrm{pA} 2=6.67 \pm 0.12)$. The pA2 values of these two antagonists in platelets are in close agreement with the $p K_{i}$ values obtained in competition experiments (respectively 8.59 and 6.93) and with pA2 values reported in the literature for their in vivo antivasopressor activity (respectively 8.62 and 6.03 ).

The observation that human platelets bear AVP receptors belonging to the vascular class suggests that platelet receptors can be used to further explore the role of vasopressin in cardiovascular homeostasis.
\end{abstract}

\section{Introduction}

The understanding of the role of vasopressin $(A V P)^{1}$ in blood pressure regulation (1) has been aided by the development of new tools such as sensitive radioimmunoassays and, more recently, specific and potent AVP antagonists acting selectively on either the renal or vascular AVP receptors (2-4). It is now

This work was presented at the 57th Scientific Sessions of the American Heart Association, 12-15 November 1984, Miami Beach, FL (Program No. 0278).

Dr. Thibonnier was a recipient of a Merck Foundation International Fellowship in Clinical Pharmacology; his present address is Department of Pharmacology, Medical College of Ohio, C.S. 10008, Toledo, OH 43699. Address reprint requests to $\mathrm{Dr}$. Thibonnier.

Received for publication 2 July 1984 and in revised form 3 July 1985.

1. Abbreviations used in this paper: AVP, arginine-8-vasopressin; GppNHp, 5'-guanylylimidodiphosphate; $\mathrm{PGE}_{1}$, prostaglandin $\mathrm{E}_{1}$.

J. Clin. Invest.

(C) The American Society for Clinical Investigation, Inc.

$0021-9738 / 85 / 11 / 1857 / 08 \quad \$ 1.00$

Volume 76, November 1985, 1857-1864 well established that endogenous AVP does play a role in the maintenance of blood pressure in several experimental conditions in animals including dehydration, hemorrhage, adrenal insufficiency, or hypertension induced by desoxycorticosterone (see Reference 1 for review). In humans, the cardiovascular role of AVP is less well documented, except for the observation that high plasma and urinary AVP levels are encountered in severe forms of human hypertension (5).

Vasopressin receptors can be classified into two main types on the basis of structure activity and radioligand binding studies with AVP analogues. The first class of receptors, termed V1, appears to mediate vasoconstriction, glycogenolysis, and platelet aggregation and acts by stimulating phosphoinositide breakdown and mobilizing calcium. The second class of receptors, termed V2, activates adenylate cyclase and is responsible for the antidiuretic action of AVP. In animal preparations, smooth muscle cells, or liver extracts are used for investigating AVP specific receptors of the vascular type $(6,7)$, whereas kidney preparations are used to study AVP renal type receptors (8). These tissues are rarely available from man. For this reason, Block et al. (9) used human mononuclear phagocytes to characterize specific AVP receptors which are presumably of the renal type. Because Haslam and Rosson (10) showed that vasopressin aggregates human platelets in the presence of calcium and thus suggested "a parallel between platelet aggregation and the contraction of smooth muscle," we attempted to demonstrate that AVP would bind specifically to these human cells and to identify the type of receptor involved. In fact, human platelet membranes possess specific binding sites for $\left[{ }^{3} \mathrm{H}\right]$ arginine-8-AVP $\left(\left[{ }^{3} \mathrm{H}\right] \mathrm{AVP}\right)$. The pharmacologic characteristics of these binding sites are consistent with those of the V1 vascular type of AVP receptor. Accordingly, platelets may become a useful tool for exploring further the cardiovascular effects of AVP in humans.

\section{Methods}

Pharmacological agents. The radioligand $\left[{ }^{3} \mathrm{H}\right] \mathrm{AVP}$ was purchased from New England Nuclear (Boston, MA). Its radiochemical purity was checked by high pressure liquid chromatography with a reverse-phase C18 column from Waters Associätes (Milford, MA) using a gradient from $23 \%$ to $29 \%$ acetonitrile and $0.01 \mathrm{M}$ ammonium acetate, $\mathrm{pH}$ 6.7. The specific activity of $\left[{ }^{3} \mathrm{H}\right] \mathrm{AVP}$ was close to $55 \mathrm{Ci} / \mathrm{mmol}$. Bovine serum albumin, AVP, creatine phosphate, creatine phösphokinase, EGTA, $\beta$ mercaptoethanol, ATP, cyclic AMP, GTP, epinephrine, 5'-guanylylimidodiphosphate $(\mathrm{GppNHp})$, forskolin, and prostaglandin $\mathrm{E}_{1}\left(\mathrm{PGE}_{1}\right)$ were obtained from Sigma Chemical Co. (St. Louis, MO). The AVP analogues listed in Table I were generous gifts of Dr. Hofbauer (Ciba-Geigy, Switzerland), Dr. Mulder (Ferring AB, Malmö, Sweden), and Dr. Manning (Toledo, $\mathrm{OH}$ ) or were purchased from Peninsula Laboratory (San Carlos, CA).

Platelet particulate preparation. Individual 50-ml units of platelet concentrates were purchased from the local blood bank. These units were prepared from $450 \mathrm{ml}$ of human blood collected into polypropylene bags containing $63 \mathrm{ml}$ of a citrate-phosphate-dextrose-adenine solution (each $63 \mathrm{ml}$ contains $2 \mathrm{~g}$ of glucose, $1.66 \mathrm{~g}$ of sodium citrate anhydrous, 
Table I. Vasopressin Structural Analogues Used

\begin{tabular}{|c|c|c|}
\hline Compound & Abbreviation & \\
\hline \multicolumn{3}{|l|}{ Agonists } \\
\hline [8-arginine]vasopressin & AVP & \\
\hline [8-lysine]vasopressin & LVP & \\
\hline Oxytocin & OXY & \\
\hline Arginine-vasotocin & AVT & \\
\hline [1-deamino, 8-D-arginine]vasopressin & dDAVP & \\
\hline [8-D-arginine] vasopressin & 8DAVP & \\
\hline [1-deamino, 8-arginine]vasopressin & dAVP & \\
\hline \multicolumn{3}{|l|}{ [2-phenylalanine, 8-orni- } \\
\hline thinejoxytocin & Phe20rn80T & \\
\hline \multicolumn{3}{|l|}{ [Deamino-dicarba, 8-argi- } \\
\hline nine]vasopressin & dDCAVP & \\
\hline \multicolumn{3}{|l|}{ Antagonists } \\
\hline $\begin{array}{l}\text { [1-deaminopenicillamine, 4-valine, } \\
\text { 8-D-arginine]vasopressin }\end{array}$ & dPVDAVP & \\
\hline \multicolumn{3}{|l|}{$\begin{array}{l}\text { [1-( } \beta \text {-mercapto- } \beta, \beta \text {-cyclopenta- } \\
\text { methylenepropionic acid), 2-(O- } \\
\text { methyl)tyrosine, } 8 \text {-argi- }\end{array}$} \\
\hline nine]vasopressin & $\mathrm{d}\left(\mathrm{CH}_{2}\right)_{5} \mathrm{Tyr}(\mathrm{Me}) \mathrm{AVP}$ & \\
\hline \multicolumn{3}{|l|}{$\begin{array}{l}\text { [1-( } \beta \text {-mercapto- } \beta, \beta \text {-cyclopenta- } \\
\text { methylenepropionic acid), 2-D-iso- } \\
\text { leucine, 4-valine, } 8 \text {-argi- }\end{array}$} \\
\hline nine]vasopressin & $\mathrm{d}\left(\mathrm{CH}_{2}\right)_{5}$ DIleu ValAVP & \\
\hline \multicolumn{3}{|l|}{$\begin{array}{l}\text { [1-( } \beta \text {-mercapto- } \beta, \beta \text {-cyclopenta- } \\
\text { methylenepropionic acid), } 2 \text {-D-iso- } \\
\text { leucine, 4-alanine, } 8 \text {-argi- }\end{array}$} \\
\hline nine]vasopressin & $\mathrm{d}\left(\mathrm{CH}_{2}\right)_{\text {s DIleuAlaAVP }}$ & $\mathbf{m}$ \\
\hline
\end{tabular}

$206 \mathrm{mg}$ of citric acid, $140 \mathrm{mg}$ of sodium biphosphate, and $17.3 \mathrm{mg}$ of adenine). The platelet concentrates were spun at room temperature for is min at $180 \mathrm{~g}$ to sediment the residual erythrocytes. The platelet-rich plasma was removed and spun at room temperature for $15 \mathrm{~min}$ at 1,165 $g$ to sediment platelets. The platelet pellet was suspended in $1.5 \mathrm{ml}$ buffer (Tris-HCl $50 \mathrm{mM}$ + EDTA $5 \mathrm{mM}$, pH 7.4) then frozen in liquid nitrogen. The preparation was allowed to thaw at room temperature and transferred to high-speed centrifuge tubes. High-speed centrifugation $(30,000 \mathrm{~g}$ for $15 \mathrm{~min}$ at $4^{\circ} \mathrm{C}$ ) was repeated three times after rinsing the pellet with 5 $\mathrm{ml}$ of cold buffer. The washed pellet was resuspended in $2.5 \mathrm{ml}$ of buffer and stored frozen at $-70^{\circ} \mathrm{C}$. All the previous steps were carried out with plastic material, and repeated saturation analysis showed that the receptor was stable under these conditions for a period of up to $3 \mathrm{mo}$.

Intact platelets were also prepared for binding experiments. The platelet-rich plasma pellet (instead of being frozen for particulate preparation) was resuspended in buffer (Tris- $\mathrm{HCl} 50 \mathrm{mM}, \mathrm{pH} 7.4, \mathrm{NaCl} 138$ $\mathrm{mM}$, EDTA $5 \mathrm{mM}$ ) and then centrifuged twice at $16,000 \mathrm{~g}$ for $15 \mathrm{~min}$ at $25^{\circ} \mathrm{C}$. The washed intact platelets $\left(1 \times 10^{6} / \mu \mathrm{l}\right)$ were resuspended in assay buffer and used the same day for binding experiments.

Hormone binding assays. For the binding assays, platelet particulate aliquots were thawed and diluted $(0.8$ to $1 \mathrm{mg} / \mathrm{ml}$ final concentration determined with Bradford's method (11) in the assay buffer containing $50 \mathrm{mM}$ Tris- $\mathrm{HCl}$ and $4 \mathrm{mM} \mathrm{MgCl}, \mathrm{pH}$ 7.4. Duplicate samples were incubated at $30^{\circ} \mathrm{C}$ in $5 \mathrm{ml}$ polypropylene plastic tubes (Sarstedt, West Germany) in a final volume of $250 \mu \mathrm{l}$ containing $1 \mathrm{mg} / \mathrm{ml}$ bovine serum albumin and different concentrations of $\left[{ }^{3} \mathrm{H}\right] \mathrm{AVP}$ ranging from 0.3 to $15 \mathrm{mM}$.

For saturation and competition analysis, the incubation time was 30 min. For competition experiments with the structural analogues of AVP, 13 concentrations of these compounds were added to the reaction mixture containing 1-2 nM [ $\left.{ }^{3} \mathrm{H}\right] \mathrm{AVP}$. Incubation was terminated by adding 5 $\mathrm{ml}$ of ice-cold assay buffer and free separated from bound $\left[{ }^{3} \mathrm{H}\right] \mathrm{AVP}$ by rapid ( $1 \mathrm{ml} / \mathrm{s}$ ) filtration over Whatman GF/C glass fiber filters (Whatman Chemical Separation, Clifton, NJ) previously soaked in assay buffer plus albumin $1 \mathrm{mg} / \mathrm{ml}$ for $1 \mathrm{~h}$. The filters were rinsed four times with $5 \mathrm{ml}$ of buffer and transferred to vials containing $4 \mathrm{ml}$ of Hydrofluor (National Diagnostics, Inc., Somerville, NJ) as scintillation fluid and the radioactivity was determined in a Packard Tricarb scintillation counter (Packard Instrument Co., Inc., Downers Grove, ILL) at an efficiency of 52\%. The stability of the tracer in the incubation medium was checked before and at the end of the incubation period by high pressure liquid chromatography and thin-layer chromatography. In saturation experiments, unspecific binding of $\left[{ }^{3} \mathrm{H}\right] A$ VP was defined as radioactivity bound to platelet particulates which was not competed by $100 \mathrm{nM}$ of unlabeled AVP. Specific binding was, therefore, defined as total binding minus unspecific binding.

Adenylate cyclase activity assay. Adenylate cyclase activity was determined by measuring the formation of $\left[{ }^{32} \mathrm{P}\right]$ cyclic AMP from [ $\alpha-$ ${ }^{32}$ PJATP (Amersham Corp., Des Plaines, IL, $23 \mathrm{Ci} / \mathrm{mmol}$ ) in an incu-

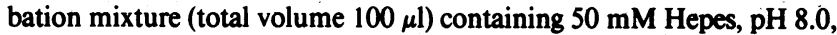
$4 \mathrm{mM} \mathrm{MgCl} 2,0.2 \mathrm{mM}$ EGTA, $100 \mathrm{mM} \mathrm{NaCl}, 2 \mathrm{mM} \beta$-mercaptoethanol, $0.1 \%$ bovine serum albumin, $10 \mathrm{mM}$ creatine phosphate, $10 \mathrm{U} / \mathrm{ml}$ creatine phosphokinase, $0.4 \mathrm{mM}$ ATP, $1 \mathrm{mM}$ cyclic AMP, $1 \mu \mathrm{Ci}$ of $[\alpha-$ $\left.{ }^{32} \mathrm{P}\right] \mathrm{ATP}, 100 \mu \mathrm{M}$ GTP, and human platelet preparation (40 $\mu \mathrm{g}$ of protein per tube). $\left[{ }^{3} \mathrm{H}\right]$ cyclic AMP (New England Nuclear, $32 \mathrm{Ci} / \mathrm{mmol}$ ) was added $(30,000 \mathrm{cpm})$ to determine recovery. For certain experiments (as noted in the results section of this paper), appropriate concentrations of AVP, epinephrine, prostaglandin $E_{1}$, and/or forskolin were added to the incubation mixture. After incubation for $10 \mathrm{~min}$ at $30^{\circ} \mathrm{C}$ (no time course study of cyclic AMP production was done), $2 \mathrm{ml}$ of a stopping solution ( $1 \%$ sodium lauryl sulfate, $10 \mathrm{mM}$ cyclic AMP, and $50 \mathrm{mM} \mathrm{ATP}$ ) was added. $\left[{ }^{32} \mathrm{P}\right]$ cyclic AMP and $\left[{ }^{32} \mathrm{P}\right] \mathrm{ATP}$ were separated according to the method of Salomon et al. (12) and the amount of [ $\left.{ }^{32} \mathrm{P}\right]$ cyclic AMP and $\left[{ }^{3} \mathrm{H}\right]$ cyclic AMP was measured in a Packard scintillation counter. Incubations were done in triplicate and the picomoles of cyclic AMP formed were calculated from the amount of $\left[{ }^{32} \mathrm{P}\right]$ cyclic AMP and corrected for the recovery as determined by $\left[{ }^{3} \mathrm{H}\right]$ cyclic AMP (usually $92 \pm 2 \%$ ).

Platelet aggregation measurement. Venous blood $(20-40 \mathrm{ml})$ was drawn on $0.01 \%$ heparin $(1,000 \mathrm{IU} / \mathrm{ml})$ by antecubital venipuncture from human volunteers who denied taking any drug for the preceding 2 wk. Platelet-rich plasma $\left(300,000\right.$ platelets $\left./ \mathrm{mm}^{3}\right)$ was prepared as described above and platelet aggregation was measured at $37^{\circ} \mathrm{C}$ in a Payton aggregometer (Payton Scientific, Inc., Buffalo, NY) connected to a Fisher Recordall recorder (Fisher Scientific Co., Pittsburgh, PA). The maximal change in light transmittance after addition of AVP or analogues was determined. When antagonism of the action of AVP by specific antagonists was studied, platelets were incubated with the antagonist for $30 \mathrm{~s}$ before addition of AVP.

Statistical evaluation. Values given in the text, figures, and tables are mean \pm SEM of $n$ experiments. Data from saturation and competition analysis were analyzed using an iterative nonlinear least squares curvefitting program. The program and the mathematical models upon which the program is based are described elsewhere (13). For saturation experiments, data analysis was done using the following equation:

$[P L]=\sum_{i=1}^{m}\left(\left[P t_{i}\right] \times[L f]\right) /\left([L f]+\left[K_{d}\right]\right)$,

where $[P L]=$ concentration of bound tracer, $\left[P t_{i}\right]=$ total concentration of receptors $i, L f=$ concentration of unbound tracer, and $K_{d}=$ dissociation constant of receptor $i$. Parameters were chosen which yielded the best data fit as determined by minimal variance of experimental data about the curve generated by these parameters. Parameter estimation was compared at increasing number of parameters and the number of parameters $(n)$ chosen was that with no statistically significant difference in residual variance over $(n+1)$ parameters. This mathematical model was used with both total binding and specific binding determined in the presence of unlabeled AVP in excess.

IC $_{s 0}$ values for inhibition of $\left[{ }^{3} \mathrm{H}\right] \mathrm{AVP}$ binding by different agonists and antagonists were determined from dose-response curves as described 
and converted into $K_{i}$ values according to the equation of Cheng and Prusoff (14);

$K_{i}=\mathrm{IC}_{50} /\left(1+L f / K_{\mathrm{d}}\right)$,

where $\mathrm{IC}_{50}$ is the concentration of the competing agent that inhibits specific $\left[{ }^{3} \mathrm{H}\right] \mathrm{AVP}$ binding by $50 \% ; L f$ is the concentration of $\left[{ }^{3} \mathrm{H}\right] \mathrm{AVP}$ (1-2 nM); and $K_{d}$ is the equilibrium dissociation constant for $\left[{ }^{3} \mathrm{H}\right] \mathrm{AVP}$ binding determined from saturation experiments.

For platelet aggregation experiments, the effect of AVP was analyzed using the following equation:

$E / E_{\max }=L /\left(L+E C_{50}\right)$,

where $E=$ degree of platelet aggregation induced by AVP for a given concentration, $E_{\max }=$ maximum effect induced by $\mathrm{AVP}, L=$ corresponding AVP concentration, and $\mathrm{EC}_{50}=$ concentration of $\mathrm{AVP}$ inducing $50 \%$ of maximum aggregation.

In the presence of a vasopressin-competitive antagonist, the following equation was used:

$E / E_{\max }=L /\left(L+\mathrm{EC}_{50} \times\left[1+I / \mathrm{I}_{50}\right]\right)$,

where $I=$ concentration of the competitive antagonist and $\mathrm{I}_{50}=$ affinity constant of this antagonist.

\section{Results}

Kinetics of $\left[{ }^{3} H\right] A V P$ binding to human platelet particulates. The amount of $\left[{ }^{3} \mathrm{H}\right] A$ VP that binds to human platelet particulate varies as a function of the protein concentration (Fig. 1). With a protein concentration between 0.2 and $1.5 \mathrm{mg} / \mathrm{ml}$, a linear increase in total and specific binding of $\left[{ }^{3} \mathrm{H}\right] \mathrm{AVP}(1-2 \mathrm{nM})$ was noted ( $r=0.99$, seven different concentrations, $n=3)$. Specific binding accounted for $52 \pm 2 \%$ of total binding. The binding of $\left[{ }^{3} \mathrm{H}\right] \mathrm{AVP}$ was also dependent on the time of incubation (Fig. 2). At a concentration of $2 \mathrm{nM}\left[{ }^{3} \mathrm{H}\right] \mathrm{AVP}$, the amount of specifically bound hormone increased with time and reached an equilibrium value of $78 \pm 2 \%$ of total binding within 30 min whereas nonspecific binding increased linearly with time $(r=0.95,11$ different time points, from 2 to $120 \mathrm{~min}, n=3$ ). The rate constant for the pseudo first-order association reaction, $K_{\text {obs }}$, was 0.128 $\mathrm{min}^{-1}$, calculated from the following formula: $\operatorname{Ln}\left(B_{\mathrm{eq}} /\left(B_{\mathrm{eq}}-B\right)\right)$ $=K_{\text {obs }} \times$ time. Specific binding of $\left[{ }^{3} \mathrm{H}\right]$ AVP was rapidly reversible, as shown in Fig. 3. To demonstrate reversibility, platelet particulates were incubated with 1-2 $\mathrm{nM}\left[{ }^{3} \mathrm{H}\right] \mathrm{AVP}$ for $30 \mathrm{~min}$; thereafter a high concentration ( $100 \mathrm{nM}$ final) of unlabeled AVP was added to the incubation mixture and specific binding was

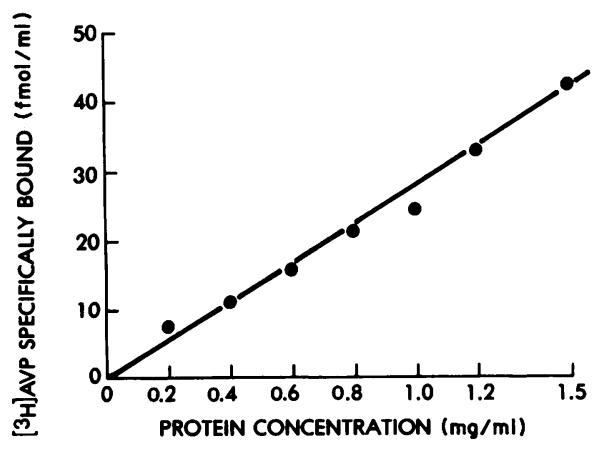

Figure 1. Specific binding of $\left[{ }^{3} \mathrm{H}\right] \mathrm{AVP}$ as a function of human platelet particulate protein concentration. Protein concentrations between 0.2 and $1.5 \mathrm{mg} / \mathrm{ml}$ were incubated with $2 \mathrm{nM}$ of $\left[{ }^{3} \mathrm{H}\right] \mathrm{AVP}$ for $30 \mathrm{~min}$ at $30^{\circ} \mathrm{C}$. Specific binding was measured in the presence of $100 \mathrm{nM}$ unlabeled hormone $(n=3, r=0.99)$.

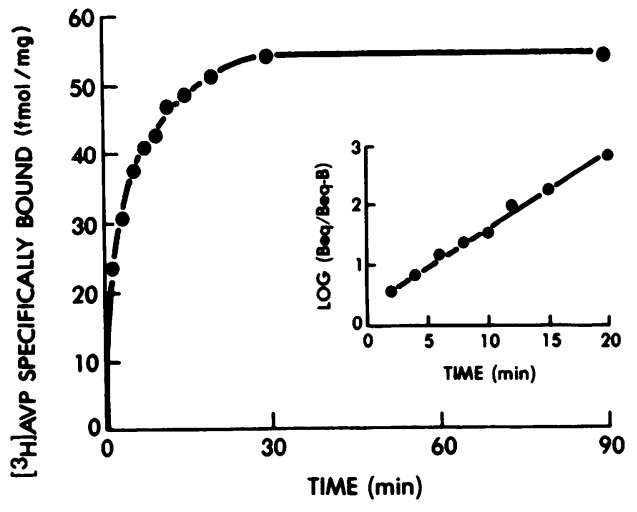

Figure 2. Specific binding of $\left[{ }^{3} \mathrm{H}\right] \mathrm{AVP}$ to human platelet particulates as a function of time. Platelet particulate preparations $(0.8-1 \mathrm{mg} / \mathrm{ml})$ were incubated with $\left[^{3} \mathrm{H}\right] \mathrm{AVP}(1-2 \mathrm{nM})$ in the presence or absence of excess unlabeled AVP $(100 \mathrm{nM})$ at $30^{\circ} \mathrm{C}$ and specific binding was determined at various time intervals between 2 and $90 \mathrm{~min}$. (Inset) Pseudo first-order kinetic plot of $\left[{ }^{3} \mathrm{H}\right] \mathrm{AVP}$-specific binding versus time: $\operatorname{Ln}\left(B_{o q} /\left(B_{e q}-B\right)=K_{o b s} \times t\right.$, where $B=$ amount of $\left[{ }^{3} \mathrm{H}\right] \mathrm{AVP}$ bound at each time $t, B_{\mathrm{eq}}=$ amount of $\left[{ }^{3} \mathrm{H}\right] \mathrm{AVP}$ bound at equilibrium, $\left(n=3, K_{\text {obe }}=0.128 \mathrm{~min}^{-1}, r=0.99\right)$.

determined at serial time intervals after AVP addition. Unlabeled AVP rapidly replaced $\left[{ }^{3} \mathrm{H}\right] \mathrm{AVP}$ from the binding sites. After 60 min almost no $\left[{ }^{3} \mathrm{H}\right] \mathrm{AVP}$ was specifically bound. The dissociation rate constant was $0.036 \mathrm{~min}^{-1}$, calculated from the formula: Ln $\left(B / B_{\text {eq }}\right)=K_{2} \times$ time. Dissociation experiments were also carried out with infinite dilution after binding (addition of 20 $\mathrm{ml}$ of buffer prewarmed at $30^{\circ} \mathrm{C}$ after the initial 30 -min incubation period). The dissociation rate constant derived from this series of experiments was $0.039 \mathrm{~min}^{-1}$, close to the value obtained from dissociation experiments performed with cold AVP in excess.

The second-order rate constant for the association reaction, $K_{1}$, can be calculated from the equation: $K_{1}=\left(K_{\text {obs }}-K_{2}\right) /$

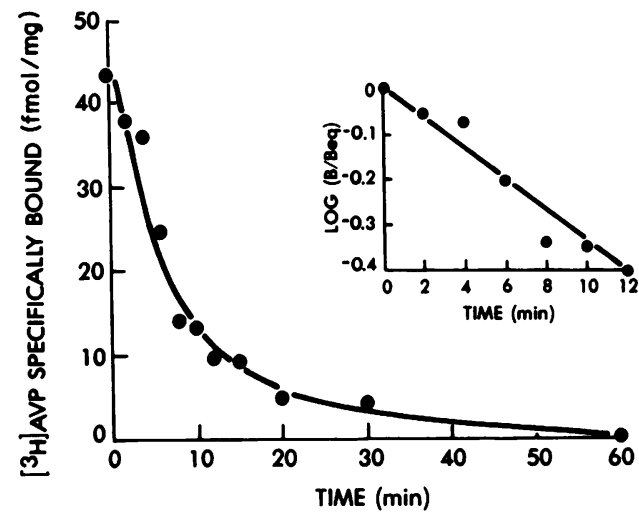

Figure 3. Reversibility of $\left[{ }^{3} \mathrm{H}\right] \mathrm{AVP}$-specific binding to human platelet particulates. Platelet particulate preparations $(0.8-1 \mathrm{mg} / \mathrm{ml})$ were incubated with [ $\left.{ }^{3} \mathrm{H}\right] \mathrm{AVP}(1-2 \mathrm{nM})$ for $30 \mathrm{~min}$ at $30^{\circ} \mathrm{C}$, after which an excess of unlabeled AVP ( $100 \mathrm{nM}$ final concentration) was added. The time of unlabeled AVP addition was defined as $t=0$ and $\left[{ }^{3} \mathrm{H}\right] \mathrm{AVP}$ specific binding was determined at the indicated subsequent time intervals. (Inset) First-order kinetic plot of the dissociation of $\left[{ }^{3} \mathrm{H}\right] \mathrm{AVP}$ binding versus time: $\operatorname{Ln}\left(B / B_{\infty q}\right)=K_{2} \times t$, where $B=$ amount of $\left[{ }^{3} \mathrm{H}\right] \mathrm{AVP}$ bound at each time $t$ after the addition of unlabeled AVP, $B_{\text {eq }}=$ amount of $\left[{ }^{3} \mathrm{H}\right]$ AVP bound immediately prior to the addition of unlabeled AVP, $\left(n=3, K_{2}=0.036 \mathrm{~min}^{-1}, r=-0.97\right)$. 
$\left(\left[{ }^{3} \mathrm{H}\right] \mathrm{AVP}\right)$, where $\left[{ }^{3} \mathrm{H}\right] \mathrm{AVP}=$ concentration of tritiated AVP used in the experiment. It was $0.043 \times 10^{9} \mathrm{M}^{-1} \times \mathrm{min}^{-1}$. Thus, the equilibrium dissociation constant $\left(K_{\mathrm{d}}\right)$ for $\left[{ }^{3} \mathrm{H}\right] \mathrm{AVP}$ binding determined from the ratio $K_{2} / K_{1}$ was $0.83 \mathrm{nM}$.

Concentration of $\left[{ }^{3} \mathrm{H}\right] \mathrm{AVP}$ binding sites in platelet particulates. Total binding for a series of 12 saturation experiments, expressed as a fraction of total ligand concentration, ranged from $7.8 \pm 0.2 \%$ to $1.9 \pm 0.01 \%$, when tracer concentration was increased from $0.21 \pm 0.02 \mathrm{nM}$ to $15.04 \pm 0.95 \mathrm{nM}$. Nonspecific binding increased linearly from $27 \pm 3 \%$ to $70 \pm 4 \%$ of total binding when free ligand concentration was raised from 0.21 to 15.04 $\mathrm{nM}(r=0.99)$.

Specific binding of $\left[{ }^{3} \mathrm{H}\right] A$ VP increased with $\left[{ }^{3} \mathrm{H}\right] \mathrm{AVP}$ concentrations reaching a steady state between $3 \mathrm{nM}$ and $6 \mathrm{nM}$. A typical binding experiment is shown in Fig. 4. Computer analysis using total binding data indicated the presence of one class of high-affinity binding sites $\left(K_{\mathrm{d}}=1.01 \pm 0.06 \mathrm{nM}\right.$, maximal concentration of binding sites $=100 \pm 10 \mathrm{fmol}$ of $\left[{ }^{3} \mathrm{H}\right] \mathrm{AVP}$ per $\mathrm{mg}$ of protein, $n=12)$ plus nonspecific binding $(0.0143 \pm 0.001)$. As predicted, computer analysis of "specific binding" data (in the presence of $100 \mathrm{nM}$ unlabeled AVP, final concentration) also indicated the presence of one class of high-affinity binding sites with identical characteristics $\left(K_{d}=1.03 \pm 0.08 \mathrm{nM}\right.$, maximal concentration of binding sites $=100 \pm 6 \mathrm{fmol}$ of $\left[{ }^{3} \mathrm{H}\right] \mathrm{AVP}$ per $\mathrm{mg}$ of protein. These $K_{\mathrm{d}}$ values are in good agreement with the value obtained from kinetic studies. GppNHp $(0.1 \mathrm{mM})$ had no significant effect on saturation experiment parameters $\left(K_{d}\right.$ $=1.05 \pm 0.09$ vs. $0.96 \pm 0.11 \mathrm{nM}$ and maximal concentration of binding sites $=96 \pm 7$ vs. $88 \pm 10 \mathrm{fmol} / \mathrm{mg}$ protein, $n=6$ ). A series of six paired saturation experiments was also performed with both platelet particulates and intact platelets prepared from the same units of platelet-rich plasma. For membrane particulates, the $K_{d}$ was $0.90 \pm 0.06 \mathrm{nM}$ and the maximal concentration of binding sites was $73 \pm 10 \mathrm{fmol} / \mathrm{mg}$ protein. For intact platelets, the $K_{\mathrm{d}}$ was $0.42 \pm 0.01 \mathrm{nM}$ and the maximal concentration of binding sites was $38 \pm 7 \mathrm{fmol} / \mathrm{mg}$ protein, which corresponds to an average of $82 \mathrm{fmol} / 10^{6}$ platelets.

Characterization of $\left[{ }^{3} \mathrm{H}\right] \mathrm{AVP}$ binding sites to human platelet particulates. Several AVP agonists were tested for their ability to compete for specific $\left[{ }^{3} \mathrm{H}\right] \mathrm{AVP}$ binding. Analysis of the agonists' competition for $\left[{ }^{3} \mathrm{H}\right] \mathrm{AVP}$ binding indicated the presence of a single and homogenous class of binding sites on human platelets (Fig. 5). The dissociation constants for AVP agonists ( $n=3$ for each analogue tested) in human platelet particulates are shown in Table II. GppNHp did not significantly modify unlabeled AVP inhibition of $\left[{ }^{3} \mathrm{H}\right] \mathrm{AVP}$ binding $\left(\mathrm{pK}_{\mathrm{d}}=8.86 \mathrm{vs.} 8.72, n=3\right.$ exp.). As indicated in Fig. 6, there was a significant correlation between the binding dissociation constant values of these agonists and their corresponding vasopressor activities $(r=0.87, P$ $=0.002$ ), whereas there was no correlation between the same binding dissociation constant and their antidiuretic potency $(r$ $=0.28, P=0.47$ ).

Vasopressin antagonists were also tested for their ability to compete for specific $\left[{ }^{3} \mathrm{H}\right] \mathrm{AVP}$ binding. Analysis of antagonists competition for $\left[{ }^{3} \mathrm{H}\right] \mathrm{AVP}$ binding sites on human platelets $(n$ $=3$ for each analogue tested). The $K_{i}$ values for inhibition of [ $\left.{ }^{3} \mathrm{H}\right] \mathrm{AVP}$ binding to human platelet particulates by AVP antagonists are listed in Table III. There was a significant correlation between the $K_{i}$ values of these antagonists and their pA2 values for the antivasoconstrictive activity $(r=0.99, P=0.007)$, whereas no such correlation was found for the pA2 value for the antidiuretic activity. Finally, serotonin, epinephrine, norepinephrine,
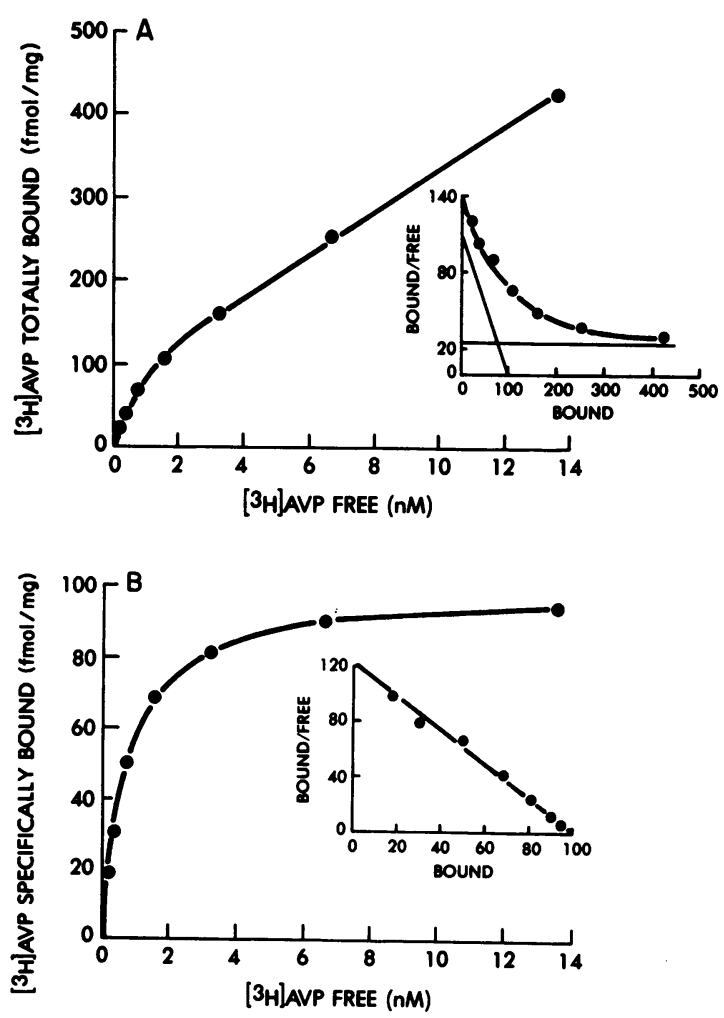

Figure 4. Binding of $\left[{ }^{3} \mathrm{H}\right] \mathrm{AVP}$ to human platelet particulates as a function of $\left[{ }^{3} \mathrm{H}\right] \mathrm{AVP}$ concentration. Platelet particulate preparations $(0.8-1 \mathrm{mg} / \mathrm{ml})$ were incubated for $30 \mathrm{~min}$ at $30^{\circ} \mathrm{C}$ with various concentrations of $\left[{ }^{3} \mathrm{H}\right] \mathrm{AVP}$ ranging from 0.3 to $15 \mathrm{nM}$. The sections show a typical experiment with a protein concentration $=1 \mathrm{mg} / \mathrm{ml}$. (Insets) Scatchard arrays of $\left[{ }^{3} \mathrm{H}\right] A$ VP binding. The ratio $B / F$ of bound $\left[{ }^{3} \mathrm{H}\right] A V P$ to free $\left[{ }^{3} \mathrm{H}\right] A V P$ is plotted as function of $B=$ bound $\left[{ }^{3} \mathrm{H}\right]$ AVP. $(A)$ Total binding of $\left[{ }^{3} \mathrm{H}\right] \mathrm{AVP}$. In that experiment, $B_{\max }$ $=104 \mathrm{fmol} / \mathrm{mg}$ and $K_{d}=0.96 \mathrm{nM}$. $(B)$ Specific binding of $\left[{ }^{3} \mathrm{H}\right] \mathrm{AVP}$ in the presence of $100 \mathrm{nM}$ of unlabeled AVP. In that experiment, $B_{\max }$ $=96 \mathrm{fmol} / \mathrm{mg}$ and $K_{d}=0.85 \mathrm{nM}$.

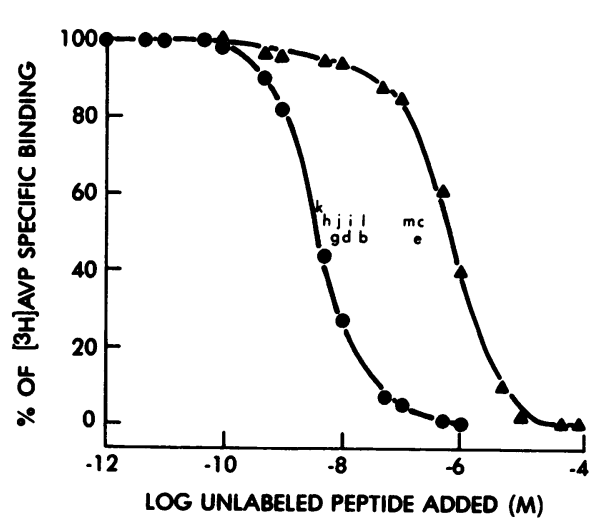

Figure 5. Inhibition by AVP analogues of $\left[{ }^{3} \mathrm{H}\right] \mathrm{AVP}$-specific binding to human platelet particulates. Platelet particulate preparations $(0.3$ to 1 $\mathrm{mg} / \mathrm{ml}$ ) were incubated with $\left[{ }^{3} \mathrm{H}\right] \mathrm{AVP}(1-2 \mathrm{nM})$ for $30 \mathrm{~min}$ at $30^{\circ} \mathrm{C}$ in the absence or presence of 13 different concentrations of the competitor, ( $n=3$ for each analogue). Solid circles represent competition with unlabeled AVP which has the highest $p K_{i}$ value (8.85), whereas solid triangles represent competition with 8DAVP, which has the lowest $\mathrm{pK}_{\mathrm{i}}$ value (6.53). The letters stand for the $\mathrm{pK}_{\mathrm{i}}$ values of the corresponding compounds listed in Table I. In all cases, data were best analyzed by a 2-parameter model indicating the presence of one class of binding sites without evidence of cooperativity. 
Table II. Affinity Constants for Binding of

Vasopressin and Agonists to Human Platelet Membranes:

Relation to Vasopressor and Antidiuretic Activities

\begin{tabular}{lllc}
\hline Compound & $\mathrm{pK}_{\mathbf{i}}$ & $\begin{array}{l}\text { Vasopressor } \\
\text { activity }\end{array}$ & $\begin{array}{l}\text { Antidiuretic } \\
\text { activity }\end{array}$ \\
\hline & & U/mg & $U / m g$ \\
AVP & 8.85 & 369 & 369 \\
Phe20rn80T & 8.54 & 120 & 0.55 \\
dAVP & 8.38 & 370 & 1390 \\
AVT & 7.92 & 196 & 274 \\
dDCAVP & 7.64 & 23 & 85 \\
LVP & 7.63 & 270 & 270 \\
dDAVP & 6.90 & 0.47 & 955 \\
OXY & 6.78 & 4 & 4.3 \\
8DAVP & 6.53 & 1.1 & 257 \\
& & & \\
\hline
\end{tabular}

For abbreviations, see Table I. Values of $\mathrm{pK}_{\mathrm{i}}$ are the mean of three independent determinations obtained as indicated in the legend to Fig. 5. $\mathrm{pK}_{\mathrm{i}}=-\log K_{i}, K_{\mathrm{i}}=$ dissociation constant (M). Pharmacologic data (vasopressor and antidiuretic activities) come from References $2-4,6$, 17,29 , and 30.

acetylcholine, and angiotensin II (at concentrations up to $10^{-3}$ M) did not compete for $\left[{ }^{3} \mathrm{H}\right] \mathrm{AVP}$ binding.

Effect of AVP on adenylate cyclase activity. The production of cyclic AMP in basal conditions was $28 \pm 3 \mathrm{pmol} / \mathrm{mg}$ of protein $\cdot \min$ and was not altered by the addition of GTP $\left(10^{-4} \mathrm{M}\right)$ $(26 \pm 3 \mathrm{pmol} / \mathrm{mg}$ of protein $\cdot \mathrm{min})$. Sodium chloride, by itself, did not significantly alter the basal production of cyclic AMP. AVP did not further stimulate cyclic AMP production with the same conditions (Fig. $7 \mathrm{~A}$ ). On the contrary, AVP reduced basal cyclase activity by, respectively, $2 \%$ for $10^{-15} \mathrm{M} \mathrm{AVP}, 12 \%$ for $10^{-10} \mathrm{M}$ AVP, and $22 \%$ for $10^{-6} \mathrm{M}$ AVP. No further inhibition was observed for greater AVP concentrations (i.e., $10^{-5}$ and $10^{-4} \mathrm{M}$ ). The specific vascular antagonist, $\mathrm{d}\left(\mathrm{CH}_{2}\right)_{5} \mathrm{Tyr}(\mathrm{Me}) \mathrm{AVP}\left(10^{-8} \mathrm{M}\right)$, completely reversed the inhibitory effect of AVP, whereas 100 times larger doses $\left(10^{-6} \mathrm{M}\right)$ of the renal antagonist, $\mathrm{d}\left(\mathrm{CH}_{2}\right)_{5} \mathrm{DIleu}^{2} \mathrm{Ala}^{4} \mathrm{AVP}$ were required to obtain the same result. Both antagonists alone had no influence by themselves on cyclic AMP levels. By comparison, $10^{-4} \mathrm{M}$ epinephrine reduced basal adenylate cyclase activity by $30 \%(n=11$ for the entire series of experiments).

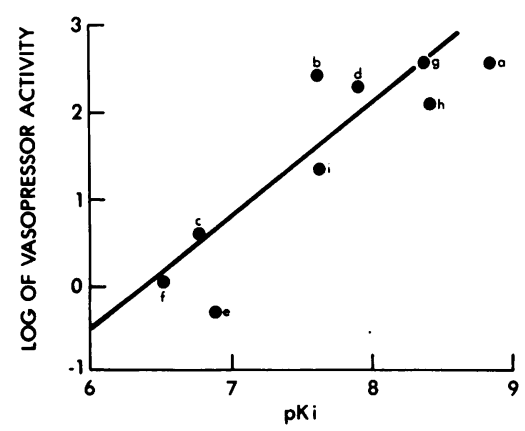

Figure 6. Relationship between AVP agonists binding to human platelet particulates and their vasopressor activities in vivo. The graph was constructed using data given in Table II. $\mathrm{pK}_{\mathrm{i}}=-\log K_{i}, K_{i}=$ binding dissociation constant at equilibrium for the corresponding analogue, (M). For vasopressor activities references, see Table II.
Table III. Inhibition Constants for Binding of Vasopressin Antagonists to Human Platelet Membranes:

Relation to Antivasopressor and Antiantidiuretic Activities

\begin{tabular}{llll}
\hline Command & $\mathrm{pK}_{\mathrm{i}}$ & $\begin{array}{l}\mathrm{pA2} \\
\text { Antivasopressor }\end{array}$ & $\begin{array}{l}\mathrm{pA2} \\
\text { Antiantidiuretic }\end{array}$ \\
\hline $\mathrm{d}\left(\mathrm{CH}_{2}\right)_{5}$ Tyr(Me)AVP & 8.59 & 8.62 & agonist $(0.3 \mathrm{U} / \mathrm{mg})$ \\
dPVDAVP & 8.02 & 7.82 & agonist $(123 \mathrm{U} / \mathrm{mg})$ \\
$\mathrm{d}\left(\mathrm{CH}_{2}\right)_{5}$ DIleuValAVP & 7.33 & 6.94 & 7.98 \\
$\mathrm{~d}\left(\mathrm{CH}_{2}\right)_{5}$ DlleuAlaAVP & 6.93 & 6.03 & 7.76 \\
& & & \\
\hline
\end{tabular}

For abbreviations, see Table I. Values of $\mathrm{pK}_{\mathrm{i}}$ are the mean of three independent determinations obtained as indicated in the legend to Fig. 5. $\mathrm{pK}_{\mathrm{i}}=-\log K_{i} ; K_{i}=$ dissociation constant (M). $\mathrm{pA} 2$ is the negative logarithm of the molar concentration of antagonist that reduces the response to $2 \times$ units of agonist to equal the response to $1 \times$ units in the absence of antagonist. Values in the Table are in vivo pA2 values from References $2-4$. They were estimated by assuming a volume of distribution of the antagonist equal to that of vasopressin.

$10^{-6} \mathrm{M} \mathrm{PGE}_{1}$ increased cyclic AMP production to $465 \pm 90$ $\mathrm{pmol} / \mathrm{mg}$ of protein $\cdot \min ($ Fig. $7 \mathrm{~B}$ ). Only the greatest concentration of AVP $\left(10^{-6} \mathrm{M}\right)$ was able to reverse partially the stimulatory effect of $\mathrm{PGE}_{1}(-17 \%)$ to the same extent as epinephrine $10^{-4} \mathrm{M}(-15 \%),(n=8$ for the entire series of experiments).

In the presence of forskolin $10^{-4} \mathrm{M}$, cyclic AMP production increased to $719 \mathrm{pmol} / \mathrm{mg}$ of protein $\cdot \min$ (Fig. 7 C). The addition of AVP did not significantly modify forskolin action whereas epinephrine $10^{-4} \mathrm{M}$ partially blocked it (-9\%).

Effect of AVP on platelet aggregation with or without specific antagonists. AVP induced aggregation of platelets in heparinized platelet-rich plasma in a dose-dependent fashion with $\mathrm{EC}_{50}$ $=28 \pm 2 \mathrm{nM}(n=8$ exp. $)$. Neither the vascular antagonist $\mathrm{d}\left(\mathrm{CH}_{2}\right)_{5} \mathrm{Tyr}(\mathrm{Me}) \mathrm{AVP}$ nor the renal antagonist $\mathrm{d}\left(\mathrm{CH}_{2}\right)_{5}$ DIleuAlaAVP had any effect on platelet aggregation when used alone (data not shown). The vascular antagonist (Figs. 8 and 10) potently blocked the aggregating action of AVP with a pA2 value of $8.10 \pm 0.23(n=4)$, whereas much greater concentrations of the renal antagonist (Fig. 9 and 10) were required in order to exert the same effect $(\mathrm{pA} 2=6.67 \pm 0.12, n=4)$. The $\mathrm{I}_{50}$ values for the vascular and renal antagonists in these experiments were respectively $8 \pm 2$ and $232 \pm 4 \mathrm{nM}$, in the same order of magnitude of their corresponding $K_{i}$ values derived from the competition experiments of AVP binding to platelet particulates.

\section{Discussion}

This study shows that blood platelets may prove a convenient biological tool for exploration of AVP receptors in man. It also further supports the observations of Haslam and Rosson (10) that human platelet $A V P$ receptors belong to the $V 1$ or vascular class. $\left[{ }^{3} \mathrm{H}\right] \mathrm{AVP}$ specifically binds to a low-capacity, high-affinity single class of sites on human platelet particulates. $\left[{ }^{3} \mathrm{H}\right] \mathrm{AVP}$ specific binding is saturable with time, it is dependent on the concentration of both the ligand and protein preparation, and it is reversible. The $k$-off values generated from our dissociation experiments with either cold AVP in excess $\left(0.036 \mathrm{~min}^{-1}\right)$ or with infinite dilution $\left(0.039 \mathrm{~min}^{-1}\right)$ fall within the range reported for other vasopressin receptor preparations (from $0.035 \mathrm{~min}^{-1}$ for pig renal medullary membrane receptors to $0.13 \mathrm{~min}^{-1}$ for pig LLC-PKI cells, cf. Table II of Reference 21). The same applies 

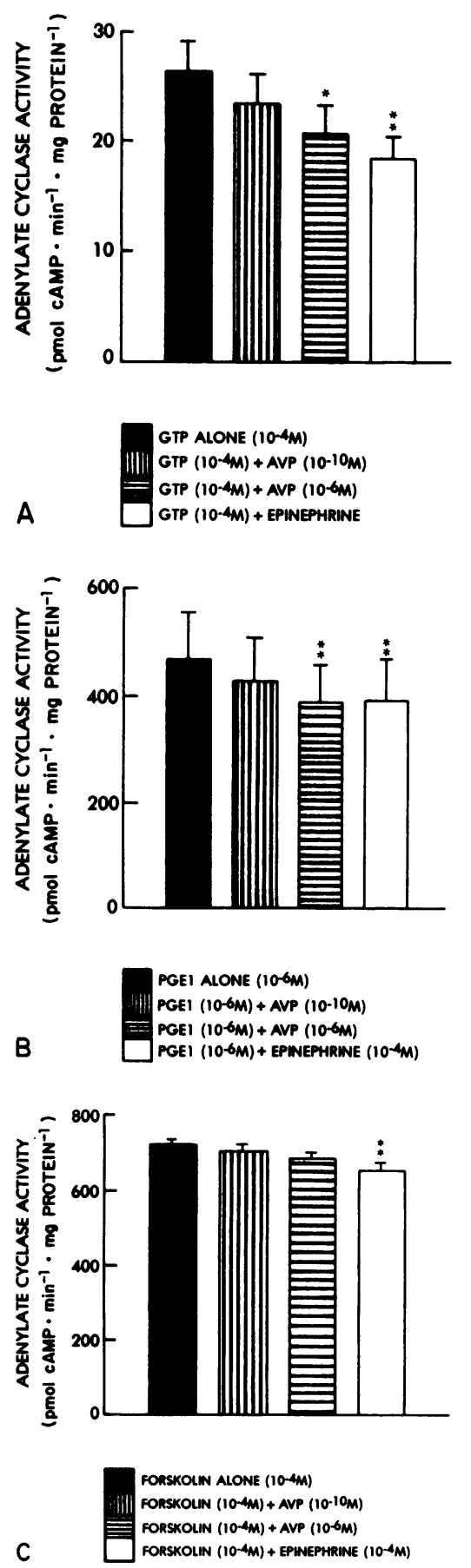

Figure 7. Effect of AVP on adenylate cyclase activity of human platelet particulates. Platelet particulate preparations $(20-40 \mu \mathrm{g})$ were incubated for $10 \mathrm{~min}$ at $30^{\circ} \mathrm{C}$ in the presence of indicated concentrations of AVP, epinephrine, $\mathrm{PGE}_{1}$ and/or forskolin. After testing homogeneity of variance of the data with Levene's test, statistical analysis used two-way analysis of variance on blocked data and Dunnett's procedure for multiple comparisons, $\left(^{*}=P<0.05,{ }^{* *}=P<0.01\right)$. $(A)$ Effect of AVP or epinephrine alone $(n=11)$. (B) Effect of AVP or epinephrine in the presence of $\mathrm{PGE}_{1}(n=8)$. (C) Effect of AVP or epinephrine in the presence of forskolin $(n=8)$.

to our $k$-on value, $4.3 \times 10^{7} \mathrm{M}^{-1} \times \mathrm{min}^{-1}$, falling within the 1.1 to $6.7 \times 10^{7} \mathrm{M}^{-1} \times \mathrm{min}^{-1}$ range reported by others (see Reference 21). The analysis of binding at equilibrium revealed an apparent equilibrium dissociation constant at $1.01 \mathrm{nM}$. The dissociation

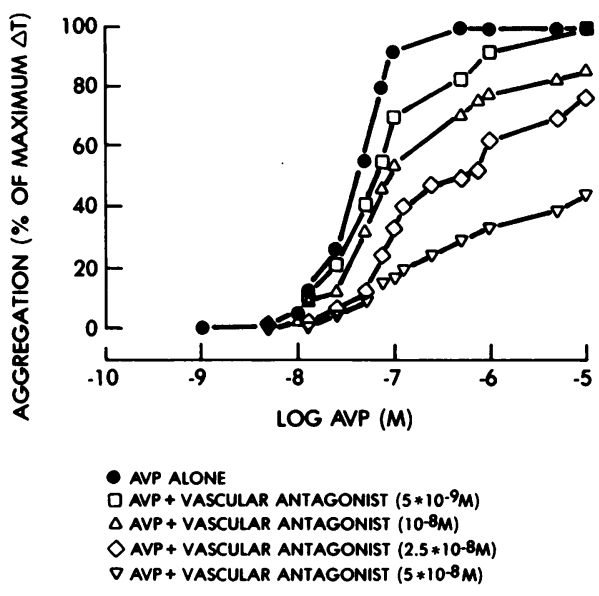

Figure 8. Aggregation of platelets in human heparinized platelet-rich plasma induced by AVP alone or in the presence of four different concentrations of the specific vascular antagonist $d\left(\mathrm{CH}_{2}\right)_{5} \mathrm{Tyr}(\mathrm{Me})$ AVP.

constant value obtained from the kinetic experiments was 0.83 $\mathrm{nM}$, and that value derived from the competition experiments with unlabeled AVP was $1.22 \mathrm{nM}$. These values are consistent and are in agreement with the dissociation constant values reported in the literature for AVP-specific receptors, which range from 0.4 to $38 \mathrm{nM}$, varying with the type of preparation and the species investigated (6-9, 15-21). The same applies to the maximum binding capacity of our preparation $(100 \mathrm{fmol} / \mathrm{mg})$, which is within the range reported in the literature for AVP receptor concentrations in different tissues (21). It is worth noting that the binding parameters estimates that we found were identical, whether we used total binding data or so-called specific binding data in the presence of an excess of unlabeled hormone. It indicates that our mathematical model, as would be predicted, adequately fitted the binding parameters $K_{d}$ and $B_{\max }$, therefore, making it unnecessary to include experimental data points with unlabeled hormone. The traditional approach of using excess unlabeled hormone can introduce error. In addition, one may consider this alternative and practical method when characterizing a new receptor without previous information about the affinity ratio between the high-affinity binding site and nonsatu-

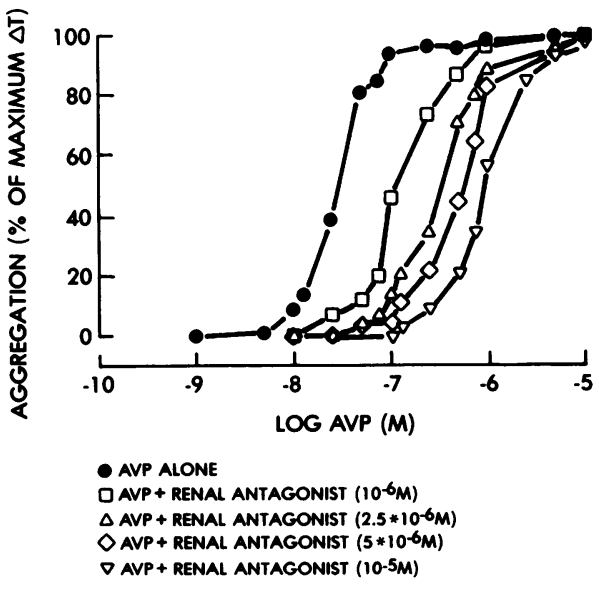

Figure 9. Aggregation of platelets in human heparinized platelet rich plasma induced by AVP alone or in the presence of four different concentrations of the specific renal antagonist $\mathrm{d}\left(\mathrm{CH}_{2}\right)_{5}$ DIleuAla AVP. 


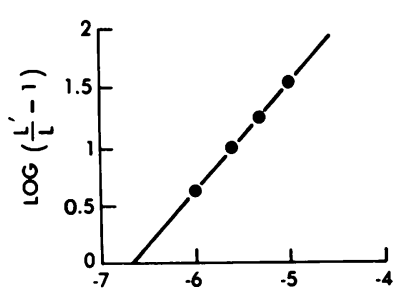

LOG RENAL ANTAGONIST (M)

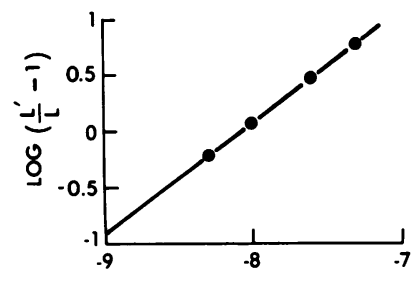

LOG VASCULAR ANTAGONIST (M)
Figure 10. Shild plots of the effects of the vascular and renal antagonists on AVP-induced platelet aggregation. $\log \left(\left(L^{\prime} / L\right)-1\right)=\log I$ - Log $I_{50}$, where $L$ and $L^{\prime}=$ concentrations of AVP alone and in the presence of the antagonist causing half-maximal platelet aggregation and $p A 2=\log I_{50}$. Values are the mean of four separate experiments for each antagonist. pA2 values were respectively $8.10 \pm 0.23$ and $6.67 \pm 0.12$ for the vascular and renal antagonists. The corresponding slopes are 0.99 and 0.92 .

rable binding. In that case, it is difficult to choose the appropriate concentration of the unlabeled hormone which is supposed to compete only for the high-affinity site. Saturation experiments performed with intact platelets also show the existence of one single class of low-capacity high-affinity binding sites whose capacity and affinity fit well with the values reported in the literature for other intact cells preparations $(21,22)$.

The V1 (vascular type) and V2 (renal type) AVP receptors clearly differ with respect to the specificity of their respective binding sites and to their coupling with the adenylate cyclase system. In our study, we have used several approaches to show that AVP receptors present on human platelets are of the $\mathrm{V} 1$ vascular type.

Previous studies have shown that AVP receptors from several species discriminate among neurohypophyseal peptides and closely related synthetic structural analogues $(6-8,15-18)$. For the series of agonists we tested in competition experiments, we found a highly significant correlation between their relative affinities for binding to the preparations and their relative vasopressor potencies in vivo, whereas no correlation between binding affinities and antidiuretic potencies was disclosed. Such specificity for the hormonal binding-effect relationship suggests that the binding sites on human platelets are of the V1 (vascular) type. This notion is supported by the significant correlation found between the apparent affinities of AVP antagonists for binding and their corresponding vascular pA2 values and by the lack of correlation between their binding affinities and their renal pA2 values. Finally, other potent vasoactive agents such as epinephrine, norepinephrine, serotonin, acetylcholine, and angiotensin II did not interfere with $\left[{ }^{3} \mathrm{H}\right] \mathrm{AVP}$ binding, confirming the specificity of $\left[{ }^{3} \mathrm{H}\right] \mathrm{AVP}$ binding.

In competition and saturation experiments, no significant effect of a synthetic analogue of GTP, GppNHp, on the affinity and capacity of the human platelet AVP receptor was detected. Such lack of effect of this nucleotide was also found for the hepatocyte receptor and the mesenteric arteries receptor (other V1-vascular type receptors), whereas it is fully effective at the V2-renal receptor level (22). The absence of effect of GppNHp on the affinity of the platelet vasopressin receptor suggests that this receptor is not directly coupled to the adenylate cyclase system.

The effect of AVP on cyclic AMP production is a valuable tool for differentiating renal type receptors (stimulating cyclic
AMP production) from vascular-type receptors (acting through calcium mobilization). In this study, the absence of increased cyclic AMP production in the presence of physiologic amounts of AVP and even the reduction of cyclic AMP production for a higher vasopressin concentration (known to cause a maximum increase in cAMP production by renal receptors [21, 22]) argue against a renal type of receptor on human platelets. This inhibitory effect of AVP on platelet particulate production of cyclic AMP recently has been reported by Vanderwel et al. (23). These authors also found that AVP concentration causing half-maximal inhibition of adenylate cyclase activity was $1.2 \pm 0.4 \mathrm{nM}$, in agreement with our results. The reduction of CAMP production by $10^{-6} \mathrm{M}$ AVP was also observed in the presence of a stimulus like $\mathrm{PGE}_{1}$. No increase of cAMP production by vasopressin in a preparation stimulated by forskolin is clearly distinct from the synergism of vasopressin and forskolin recently reported for renal medullary tubules (24).

However, previous observations using intact platelets (25) or cultured aortic smooth muscle cells (also bearing V1 AVP receptors [6] showed that AVP had no detectable effect on cyclic AMP production in these intact cells. Despite the fact that, in both intact and broken cell preparations, AVP did not stimulate cyclic AMP production (therefore, ruling out a renal type receptor), one might wonder why no cyclic AMP inhibition is encountered with intact cells whereas cyclic AMP inhibition is reported with broken cell preparations. This suggests that unidentified factors may exist that modulate the effector system with which the AVP-V1 receptor complex interacts. In addition, further investigations are needed to find out whether the effect of AVP on cyclic AMP production is directly linked to the adenylate cyclase system, or whether it is secondary to the activation of cyclic GMP-dependent protein kinase $G$ and calcium dependent protein kinase C (26). Recently, Keppens and De Wulf (27) showed that vasopressin and angiotensin enhanced the activity of liver phosphodiesterase, accounting for their cyclic AMP lowering effect. Such an effect might also explain the effect of AVP on platelet cyclic AMP levels.

We confirm that AVP causes platelet aggregation with an $\mathrm{EC}_{50}$ value $(28 \mathrm{nM})$ similar to that reported by Vanderwel et al. (23) (27 nM) using the same type of preparation. Thomas et al. (28) recently reported that a selective AVP V1 antagonist $\left(\mathrm{d}\left(\mathrm{CH}_{2}\right)_{5} \mathrm{AVP}\right)$ and a selective $\mathrm{V} 2$ agonist (dDAVP) potently inhibited AVP-induced platelet aggregation. This author also showed that the response to partial agonists (oxytocin, ldeaminoAVP) was enhanced by increasing the cytosolic calcium concentration and, therefore, concluded that platelet AVP receptors were of the $\mathrm{V} 1$ vascular type. We confirm this conclusion by demonstrating that AVP-induced aggregation was inhibited more efficiently by a specific vascular antagonist $(\mathrm{pA} 2=8.10)$ than by a specific renal antagonist $(\mathrm{pA} 2=6.67)$. Moreover, the respective $\mathrm{pA} 2$ values of these two antagonists were in close agreement with previously reported $\mathrm{pA} 2$ values of these agents for in vivo antivasopressor effects (respectively 8.62 and 6.03). The close correspondence between the pA2 values of these antagonists in platelet aggregation experiments and their pKi to compete for $\left[{ }^{3} \mathrm{H}\right] \mathrm{AVP}$ binding (respectively 8.59 and 6.93 ) implies that very similar if not identical receptors mediated both effects.

The values we found for the AVP binding dissociation constant ( $1 \mathrm{nM}$ ) and for AVP-induced platelet aggregation (28 nM) are well in agreement with data in the literature but are different from each other. Vanderwel et al. (23) also noted a difference 
between AVP effect on adenylate cyclase activity of platelet particulates $\left(K_{i}\right.$ constant $\left.=1.2 \mathrm{nM}\right)$ and AVP effect on intact platelets aggregation $\left(\mathrm{EC}_{50}=27 \mathrm{nM}\right)$. This might suggest that different classes of receptors mediate the two effects. However, our data do not support this hypothesis and it is more likely that different experimental conditions (intact platelets versus platelet particulates, different temperatures of incubation, for instance) can readily explain these differences.

\section{Acknowledgments}

We are profoundly grateful to Dr. Henry R. Bourne for his invaluable assistance in the conception and realization of this work. We thank Dr. Marc Shuman and Miss Fay Weimer for guiding us in the measurement of platelet aggregation and Mrs. Jenny Zak for her excellent secretarial assistance.

Dr. Roberts is a recipient of Research Career Development Award HD-00267 from the National Institutes of Health. This work was supported by grant HD-16262 from the National Institutes of Health.

\section{References}

1. Reid, I. A., and J. Schwartz. 1984. Role of vasopressin in the control of blood pressure. Front. Neuroendocrinol. 8:177-197.

2. Manning, M., and W. H. Sawyer. 1982. Antagonists of vasopressor and antidiuretic responses to arginine vasopressin. Ann. Intern. Med. 96: 520-521.

3. Manning, M., A. Olma, W. A. Klis, and A. Kolodziejczyk. 1982. Design of more potent antagonists of the antidiuretic response to argininevasopressin. J. Med. Chem. 25:45-50.

4. Manning, M., B. Lammek, M. Kruszynski, J. Seto, and W. H. Sawyer. 1982. Design of potent and selective antagonists of the vasopressor responses to arginine-vasopressin. J. Med. Chem. 25:408-414.

5. Thibonnier, M., J. C. Aldigier, M. E. Soto, P. Sassano, J. Menard, and P. Corvol. 1981. Abnormalities and drug-induced alterations of vasopressin in human hypertension. Clin. Sci. 61:149s-152s.

6. Penit, J., M. Faure, and S. Jard. 1983. Vasopressin and angiotensin II receptors in rat aortic smooth muscle cells in culture. Am. J. Physiol. 244:E72-E82.

7. Cantau, B., S. Keppens, H. De Wulf, and S. Jard. 1980. $\left[{ }^{3} \mathrm{H}\right]$ vasopressin binding to isolated rat hepatocytes and liver membranes: regulation by GTP and relation to glycogen phosphorylase activation. J. Recept. Res. 1:137-168.

8. Guillon, G., P. O. Couraud, D. Butlen, B. Cantau, and S. Jard. 1980. Size of vasopressin receptors from rat liver and kidney. Eur. $J$. Biochem. 111:287-294.

9. Block, L. H., R. Locher, W. Tenschert, W. Siegenthaler, T. Hoffman, R. Mettler, and W. Vetter. 1981. [ $\left.{ }^{125} \mathrm{I}\right]-8-\mathrm{L}-A$-Arginine vasopressin binding to human mononuclear phagocytes. J. Clin. Invest. 68:374-381.

10. Haslam, R. J., and G. M. Rosson. 1972. Aggregation of human blood platelets by vasopressin. J. Clin. Invest. 223:958-967.

11. Bradford, M. M. 1976. A rapid and sensitive method for quantification of microgram quantities of protein. Anal. Biochem. 72:248257.

12. Salomon, Y., C. Landos, and M. Rodbell. 1974. A highly sensitive adenylate cyclase assay. Ann. Biochem. 58:541-548.

13. Murlas, C., J. A. Nadel, and J. M. Roberts. 1982. The muscarinic cholinergic receptors of airway smooth muscle: characterization by
[3H]QNB binding and contraction in vitro. J. Appl. Physiol. 52:10841091.

14. Cheng, Y., and W. H. Prusoff. 1973. Relationship between the inhibition constant $\left(\mathrm{K}_{\mathrm{i}}\right)$ and the concentration of inhibitor which causes 50 percent inhibition $\left(\mathrm{IC}_{50}\right)$ of an enzymatic reaction. Biochem. Pharmacol. 22:3099-3108.

15. Schiffrin, E. L., and J. Genest. 1983. ${ }^{3} \mathrm{H}$-vasopressin binding to the rat mersenteric artery. Endocrinology. 113:409-411.

16. Stassen, F. L., R. W. Erickson, W. F. Huffman, J. Stefankiewicz, L. Sulat, and V. D. Wiebelhaus. 1982. Molecular mechanisms of novel antidiuretic antagonists: analysis of the effects on vasopressin binding and adenylate cyclase activation in animal and human kidney. J. Pharmacol. Exp. Ther. 223:50-54.

17. Butlen, D., G. Guillon, R. M. Rajerison, S. Jard, W. H. Sawyer, and M. Manning. 1978. Structural requirements for activation of vasopressin-sensitive adenylate cyclase; hormone binding, and antidiuretic actions: effects of highly potent analogues and competitive inhibitors. Mol. Pharmacol. 14:1006-1017.

18. Keppens, S., and H. De Wulf. 1979. The nature of the hepatic receptors involved in vasopressin-induced glycogenolysis. Biochim. Biophys. Acta. 588:63-69.

19. Dorsa, D. M., L. A. Majumdar, F. M. Petracca, D. G. Baskin, and L. E. Cornett. 1983. Characterization and localization of ${ }^{3} \mathrm{H}$-arginine8-vasopressin binding to rat kidney and brain tissue. Peptides (NY). 4: 699-706.

20. Berrettini, W. H., R. M. Post, E. K. Worthington, and J. B. Casper. 1982. Human platelet vasopressin receptors. Life Sci. 30:425432.

21. Jard, S. 1983. Vasopressin isoreceptors in mammals: relation to cyclic AMP-dependent and cyclic AMP-independent transduction mechanisms. Curr. Top. Membr. Transp. 18:255-285.

22. Jard, S. 1983. Vasopressin: mechanisms of receptor activation. Prog. Brain Res. 60:383-394.

23. Vanderwel, M., D. S. Lum, and R. J. Haslam. 1983. Vasopressin inhibits the adenylate cyclase activity of human particulate fraction through V1-receptors. FEBS (Fed. Eur. Biochem. Soc.) Lett. 164:340344.

24. Murayama, N., J. L. Werness, E. Kusano, S. Christensen, and T. P. Dousa. 1984. Interaction of forskolin with vasopressin-sensitive cyclic AMP system in renal medullary tubules. J. Cyclic Nucleotide Res. 9:427-433.

25. Haslam, R. J., M. M. L. Davidson, T. Davies, J. A. Lynham, and M. D. McClenegham. 1984. Regulation of blood platelet function by cyclic nucleotides. Adv. Cyclic Nucleotide Res. 9:533-552.

26. Takai, Y., A. Kishimoto, and Y. Nishizuka. 1982. Calcium and phospholipid turnover as transmembrane signaling for protein phosphorylation. In Calcium and Cell Function. Vol. 2. W. Y. Cheung, editor. Academic Press, Inc., New York. 386-412.

27. Keppens, S., and H. De Wulf. 1984. Vasopressin and angiotensin control the activity of liver phosphodiesterase. Biochem. J. 222:277280.

28. Thomas, M. E., A. H. Osmani, and M. C. Scrutton. 1983. Some properties of the human platelet vasopressin receptor. Thromb. Res. 32: 557-566.

29. Hase, S., T. Morikawa, and S. Sakakibara. 1969. Synthesis of a biologically active analog of deamino-8-arginine-vasopressin which does not contain a disulphide bond. Experientia (Basel). 25:1239-1240.

30. Boissonnas, R. A., S. Guttmann, B. Berde, and H. Konzett. 1961. Relationships between the chemical structures and the biological properties of the posterior pituitary hormones and their synthetic analogues. Experientia (Basel). 27:377-432. 